\title{
Characterization and Pathogenicity Test of Entomopathogenic Nematode Steinernema Species-Kalro
}

\author{
C. N. Ngugi ${ }^{1}$, P. M. Wachira ${ }^{2}$, J. N. Mbaka ${ }^{1}$, S. Okoth ${ }^{2}$, S. Haukeland ${ }^{3}$, H. M. Mburu ${ }^{3}$, \\ M. Adhiambo ${ }^{3} \&$ D. K. Sirengo ${ }^{3}$ \\ ${ }^{1}$ Kenya Agricultural and Livestock Research Organisation, Nairobi, Kenya \\ ${ }^{2}$ University of Nairobi, Nairobi, Kenya \\ ${ }^{3}$ International Center of Insect Physiology and Ecology, Nairobi, Kenya \\ Correspondence: C. N. Ngugi, Kenya Agricultural and Livestock Research Organisation, Nairobi, Kenya. E-mail: \\ ceciliahngugi20@gmail.com
}

Received: December 16, 2020

Accepted: January 24, $2021 \quad$ Online Published: February 15, 2021

doi:10.5539/jas.v13n3p93

URL: https://doi.org/10.5539/jas.v13n3p93

\begin{abstract}
Entomopathogenic nematodes (EPNs) are worldwide soil-dwelling insect parasitic nematodes. They are potential pest bio-control agents a key component of Integrated Pest Management (IPM) programs. This study aimed to characterize and evaluate the pathogenicity of an EPN isolate from Kenya. The nematode was isolated from soils using insect bait technique and both morphological and molecular identification was performed. Efficacy of the isolate was evaluated against Tomato leafminer larvae (Tuta absoluta Meyrick.) using dose-based treatments of 0-control, 100, 150, 200, and 250 infective juveniles (IJs/ml). Morphological analysis revealed body length (L) of 835(659-987) $\mu \mathrm{m}$ and 1781 (1297-2097) $\mu \mathrm{m}$ from fresh IJs and males respectively. Males lacked a mucron. The isolate was characterized by the partial sequence length of $877 \mathrm{bp}$ of the ITS region. Blastn results indicated the EPN isolate had a similarity match of $81-92 \%$ with Afro-tropical Steinernema species. It matched with Steinernema sp. (AY230186.1) from Kenya at 92\% and Sri Lanka (AY230184.1). Phylogenetic analysis placed the isolate together with Steinernema sp. (AY230186.1) and (AY230184.1) with a bootstrap value of 100\%. Maximum mean larval mortality $(80 \% ; 96 \%)$ was achieved 24 and $48 \mathrm{~h}$ post-treatment at concentration $150 \mathrm{IJs} / \mathrm{ml}$. All nematode concentrations achieved over $50 \%$ mean mortality after $24 \mathrm{~h}$ period. There was a significant difference $(\mathrm{P}=0.001)$ between doses 150 and $200 \mathrm{IJs} / \mathrm{ml}$. From the study, it was concluded that the nematode isolate was Steinernema sp now referred to as Steinernema sp. Kalro (Genebank Accession MW151701). The EPN has the potential for development as a biological control agent against T. absoluta.
\end{abstract}

Keywords: entomopathogenic nematodes, morphology, molecular, ITS region, Steinernema sp. Kalro

\section{Introduction}

Entomopathogenic nematodes (EPNs) in the families' Steinernematidae and Heterorhabditidae are pathogenic to insects (Kalia et al., 2014; Gozel \& Kasp, 2015; de Brida et al., 2017), found in most soils worldwide. The EPNs free-living non-feeding stage, infective juveniles (IJs) which penetrate the insect host via body orifices or through the cuticle. Once in the hemolymph, the IJs release symbiotic bacteria that multiplies as the EPNs nourish on them and insect tissue and reproduce, killing the insect host within 24-72 hours (Kaushik \& Chaubey, 2016; Caoili et al., 2018; Yooyangket et al., 2018).

The released bacteria provide pathogenicity, degrade and breakdown host tissue, and suppress the immunity of the host. These bacteria are known to produce toxic proteins (metabolites) that render EPNs lethal to insect hosts. They produce antibiotics and enzymes in addition to toxins. The mutualism of bacteria and nematodes is vital as it inhibits the development of resistance in the host insect. The nematodes complete their lifecycle within the host insect after which they exit into the soil and lie in wait for another suitable host (Poinar Jr., \& Grewal, 2012; Sternberg \& Dillman, 2012; Kalia et al., 2014; Gozel \& Kasap, 2015).

Isolation and identification of indigenous EPNs population from their preferred conditions is a crucial step in the development of effective biological pest management. This is because such species are suited to local climatic conditions (Salvadori et al., 2012; de Brida et al., 2017; Kalia et al., 2014). Commercial use of EPNs as pest bio-agents has triggered a search for new strains and evaluation of their virulence against agricultural pests 
(Shapiro-Ilan et al., 2012). Most EPN species have not been known taxonomically, but tools for their identification have been developed. Nematode characterization is mainly based on morphological and morphometric characters which are limited due to a wide range of values/ratios among strains. There is, therefore, need for Deoxyribonucleic acid (DNA) sequence analysis for accurate identification (Liu \& Berry, 1995). Characterization of EPNs requires study of the male tail, size and shape of spicules, body size, presence or absence of mucron, and lateral lines of infective juveniles (Nguyen, 2007; Hating et al., 2009).

Tomato (Solanum lycopersicum L.), is one of the world's most commonly and extensively grown edible fruit vegetables (Asgedom et al., 2011). Kenya is ranked $6^{\text {th }}$ in tomato production in Africa with a total production of 397,007 tonnes (FAO, 2012). However, its production is constrained mainly by insect pests among them Tomato leafminer (Tuta absoluta Meyrick.) that causes yield losses of up to $100 \%$. The pest is mainly managed by chemical pesticides. Chemical pesticides are costly and pose environmental and food safety concerns. Their use on T. absoluta is also limited due to the pests' nature of the damage and its ability to develop insecticide-resistant strains (Haddi et al., 2012; Nicolopoulou-Stamati et al., 2016; Bala et al., 2019). Entomopathogenic nematode Sternernema feltiae has successfully been used as a biological control agent in the management of pests like leaf miner, thrips, and cutworms in carnation flowers in Kenya (PCPB, 2018). This has prompted a search for IPM options that are safe for humans, animals, and the environment. The study aimed to isolate, identify, and evaluate the potential use of nematode isolate as a biological control against $T$. absoluta.

\section{Materials and Methods}

\subsection{Tuta absoluta Culture}

Tuta absoluta life stages were collected from infested tomato farms to establish insect culture at Kenya Agricultural and Livestock Research Organisation (KALRO)-Horticulture Research Institute.

\subsection{Entomopathogenic Nematode Isolate Culture}

The EPN isolate was isolated from soils at KALRO-Thika and reared using the insect-baiting method as described by (Bedding \& Akhurst, 1975). The soil was collected (250 gm) and 15 pre-pupa stages of Greater wax moth (Galleria mellonella) placed on the soil in a bowl. The samples were stored at room temperature of $25 \pm 2{ }^{\circ} \mathrm{C}$ and inspected for larval mortality every $24 \mathrm{hr}$. The infected G. mellonella cadavers showing typical symptoms of EPN infection were collected, cleaned in distilled water, and nematodes harvested according to White (1927). The EPN infective juvenile (IJs) were stored at $25 \pm 2{ }^{\circ} \mathrm{C}$. The EPN culture was referred to as nematode isolate.

\subsection{Morphological Identification of Nematode Isolate}

The newly collected nematode isolate was reared in vivo in the pre-pupa stage of Galleria mellonella larvae. The G. mellonella cadavers were dissected on the $3^{\text {rd }}$ day to obtained 20 males of the nematode. In the 4-6 day, 20 emerging infective juveniles IJs were picked from $G$. mellonella cadaver.

Fresh IJs and males were killed at $50-60{ }^{\circ} \mathrm{C}$ in a water bath for 3 minutes and fixed in 2-3 drops of Triethanoalamine formalin (TAF) (Courtney et al., 1955). After $48 \mathrm{~h}$, the fixed nematodes were mounted on glass slides with coverslips supported by wax to avoid flattening them sealed with nail varnish. Nematode morphology was studied according to Nguyen (2007) using a compound microscope, Leica Suit, DM 750 (Leica Microsystems Switzerland Ltd.).

\subsection{Molecular Characterization of Nematode Isolate}

Nematode infected G. mellonella cadavers were surface sterilized in $70 \%$ alcohol and dissected to get gravid females. The females were preserved in $50 \mu \mathrm{l}$ of $95 \%$ alcohol and stored at $4{ }^{\circ} \mathrm{C}$. Genomic DNA was extracted according to Razia et al. (2011), Caoili et al. (2017), protocols with modifications. The preserved nematode samples of gravid females were rehydrated in distilled water overnight $(12 \mathrm{~h})$. The obtained DNA was quantified and purified on a spectrophotometer and stored at $-40{ }^{\circ} \mathrm{C}$ for later use.

The PCR amplification of the ITS region of the local nematode isolate was performed, in $12.5 \mu 1$ of $10 \times$ of PCR master mix (Bio lab, England). The TW81 (5'-GTTTCCAGTAGGTGAACCTGC-3'), forward and AB28 (5'-ATATGCTTAAGTTCAGCGGGT-3') reverse primers were used for the partial gene amplification (Joyce et al., 1994). Thermocycler (ProFlex PCR System Applied biosystem) conditions were set at $94{ }^{\circ} \mathrm{C}$ for $5 \mathrm{~min}, 94{ }^{\circ} \mathrm{C}$ for $1 \mathrm{~min}, 55^{\circ} \mathrm{C}$ for $1 \mathrm{~min}, 72{ }^{\circ} \mathrm{C}$ for $2 \mathrm{~min}$ and $72{ }^{\circ} \mathrm{C}$ for $5 \mathrm{~min}$ all at 35 cycles per min. Electrophoresis of PCR products $(5 \mu \mathrm{l})$ was run at 100 volts for an hour. The products were sequenced by Microgen, Korea.

The sequence was edited using BioEdit v 7.0.5 Sequence Alignment Editor Software (Hall, 1999). Correction of the alignment was performed manually while multiple sequence alignment was done using MUSCLE on SeaView version 4 Alignment and analysis program (Edgar, 2004; Gouy et al., 2010). A similarity search of the 
deduced consensus sequence of EPN from the NCBI database was then done using Basic Local Alignment Search Tool (BLASTn) at (https://blast.ncbi.nlm.nih.gov) (Altschul et al., 1990; Altschul et al., 1997).

The evolutionary relationship of the nematode isolate was compared to 16 selected blastn hits. The EPN Heterorhabditis safricana (EF88006) was used as an out-group for taxonomic comparison, Phylogenetic analysis was performed using Neighbour-Joining, Distance method on SeaView version 4 program (Edgar, 2004; Gouy et al., 2010). Branch length was estimated with 1000 bootstrap replications at a $70 \%$ threshold for relatedness for the automatically generated phylogenic tree.

\subsection{Insecticidal Activity of the Nematode Isolate}

Experimental infections were carried to determine the efficacy of the isolate against Tuta absoluta larvae. Nematode infective juveniles (IJs) concentration $(0,100,150,200$, and 250) in $1 \mathrm{ml}$ of nematode suspension was determined. The insect larvae were collected from tomatoes established and maintained in a screen house. On a sterile $9 \mathrm{~cm}$, petri dish lined with white cotton cloth Five $T$. absoluta larvae were singly placed for each treatment. The experiment was a completely randomized design (CRD) with five treatments (Control and 100, 150, 200, and $250 \mathrm{IJs}$ in $1 \mathrm{ml}$ of distilled water). The Control treatment was $1 \mathrm{ml}$ of distilled water without nematodes. Each treatment with five larvae was replicated five times $(\mathrm{N}=25)$. To confirm nematode pathogenicity, $\mathrm{T}$. absoluta larvae cadavers were randomly selected from each treatment and dissected under the microscope. Data on larval mortality was recorded every $24 \mathrm{hr}$ for two days.

\subsection{Statistical Analysis}

Morphometric data were analyzed using Microsoft Office Excel 2010. Data on larval mortality was subjected to analysis of variance using GenStat Software, $15^{\text {th }}$ edition. Means were separated using Fisher's protected least significant difference test at $1 \%$ significance level.

\section{Results}

\subsection{Morphology of Entomopathogenic Nematode}

The length of the IJs body (L) was 835 (658.6-986.9) $\mu \mathrm{m}$ and a maximum body width (MBW) of $47 \mu \mathrm{m}$ (39-55.3). The excretory pore (EP) distance from the anterior end, was 81(62.7-95.6) $\mu \mathrm{m}$ and hyaline tissue $(\mathrm{H})$ of $20(13.5-25.0) \mu \mathrm{m}$ long. The body of the IJs gradually tapered anteriorly and posteriorly. Males body length was 1781 (1296.6-2096.9) $\mu \mathrm{m}$ with a maximum body width (MBW) of 113 (90.2-162.7) $\mu \mathrm{m}$. Spicule (SPL) was 82 (57.9-128.3) $\mu \mathrm{m}$ long and golden brown. The posterior end of the male body was strongly ventrally $\mathrm{J}$ curved almost spiral, gubernaculum (GL) was $45(34.5-54.9) \mu \mathrm{m}$ and the testis was ventrally reflexed and monarchic (Table 1). 
Table 1. Morphometrics of entomopathogenic nematode isolate

\begin{tabular}{|c|c|c|}
\hline Characters & Fresh infective juveniles & Fresh 1st generation males \\
\hline $\mathrm{n}$ & 20 & 20 \\
\hline $\mathrm{L}$ & $834.5 \pm 87.4(658.6-986.9)$ & $1781.3 \pm 195.1(1296.6-2096.9)$ \\
\hline EP & $81.2 \pm 7.1(62.7-95.6)$ & $106.37 \pm 13.8(84.5-140.1)$ \\
\hline MBW & $47 \pm 4.2(39-55.3)$ & $113.5 \pm 20.9(90.2-162.7)$ \\
\hline ES & $106.57 \pm 12.8(71-118.9)$ & $119.39 \pm 13.8(93.1-150.8)$ \\
\hline $\mathrm{T}$ & $53.22 \pm 8.4(40.3-71.5)$ & $19.97 \pm 2.8(14.2-25.7)$ \\
\hline ABW & $21.9 \pm 2.8(16.5-25.9)$ & $33.2 \pm 4.9(25.6-45)$ \\
\hline a & $17.8 \pm 1.1(16.3-19.7)$ & $16 \pm 2.2(12.4-19.5)$ \\
\hline $\mathrm{b}$ & $8.0 \pm 1.57(5.9-12.2)$ & $15.1 \pm 2.2(10.8-19.4)$ \\
\hline $\mathrm{c}$ & $15.9 \pm 2.3(11.86-20.5)$ & $91.4 \pm 18.6(57.8-125.6)$ \\
\hline$c^{\prime}$ & $2.5 \pm 0.3(1.8-3)$ & NA \\
\hline $\mathrm{H}$ & $20.5 \pm 3.3(13.5-25.0)$ & NA \\
\hline SPL & NA & $82.1 \pm 13.9(57.9-128.3)$ \\
\hline GL & NA & $45.3 \pm 5.9(34.5-54.9)$ \\
\hline $\mathrm{SW} \%$ & NA & $73.6 \pm 13(50.9-89.5)$ \\
\hline $\mathrm{GS} \%$ & NA & $56.3 \pm 10.3(37-86.3)$ \\
\hline $\mathrm{D} \%$ & $77.6 \pm 14.0(61.8-114.1)$ & $89.18 \pm 6.5(77.7-100.8)$ \\
\hline $\mathrm{E} \%$ & $291.2 \pm 34.7(219.0-363.8)$ & $542.7 \pm 105.1(424.4-785.4)$ \\
\hline $\mathrm{H} \%$ & $2.47 \pm 0.45(1.65-3.37)$ & NA \\
\hline
\end{tabular}

Note. $\overline{\mathrm{NA}}=$ Data not available; $\mathrm{H} \%=\mathrm{H} / \mathrm{TL} \times 100 ; \mathrm{L}=$ body length; $\mathrm{MBW}=$ maximum body width, $\mathrm{ABW}=$ anal body width; $\mathrm{a}=\mathrm{L} / \mathrm{MBW} ; \mathrm{b}=\mathrm{L} / \mathrm{ES} ; \mathrm{c}=\mathrm{L} / \mathrm{T} ; \mathrm{c}^{\prime}=\mathrm{T} / \mathrm{ABW} ; \mathrm{D} \%=\mathrm{EP} / \mathrm{ES} \times 100 ; \mathrm{E} \%=\mathrm{EP} / \mathrm{T} \times 100 ; \mathrm{GS} \%=$ $\mathrm{GL} / \mathrm{SPL} \times 100 ; \mathrm{SW} \%=\mathrm{SPL} / \mathrm{ABW} \times 100 ; \mathrm{T}=$ tail length; $\mathrm{ES}=$ distance from anterior end of end to base of basal bulb; $\mathrm{EP}=$ distance from anterior end to base of excretory pore; SPL $=$ spicule length, GL $=$ gubernaculum length; $\mathrm{n}=$ sample number.

\subsection{Molecular Characterization}

The nematode sequence partial length of the ITS of the rDNA sequence was 877 base pairs (bp). BLASTn results of the ITS region revealed sequence maximum identities of $81-92 \%$ with Steinernematidae nematodes. The study nematode showed sequence similarity of $92 \%$, with a Steinernema sp. (AY230186.1 from Kenya); 87\%, Steinernema sp (AY230184.1); from Sri Lanka 85\%, Steinernema sp. (KT358812.1); from Tanzania 84\% with Steinernema. karii (AY230173.1 from Kenya; 83\% Steinernema ethiopense (JN651414.1) from Ethiopia and 85\% with Steinernema spp. KT358811.1) from Tanzania. The EPN species with the closest match with the isolate were afro-tropical in origin (Table 2). 
Table 2. Species used in the phylogenetic analysis of the ITS gene region of the present Steinernema sp. Kalro

\begin{tabular}{llllllll}
\hline Name of close relatives & Sequence length (Bp) & Max score & E-value & $\%$ identity & Query cover & Accession no. & Country of origin \\
\hline Steinernema sp. & 1012 & 1027 & 0.0 & 92 & 84 & AY230186 & Kenya \\
Steinernema sp. & 1010 & 822 & 0.0 & 87 & 84 & AY230184 & Sri Lanka \\
Steinernema sp. & 939 & 488 & $2 \mathrm{e}-133$ & 85 & 58 & KT358812 & Tanzania \\
Steinernema karii & 988 & 488 & $2 \mathrm{e}-133$ & 84 & 63 & AY230173 & Kenya \\
S. ethiopense & 739 & 486 & $6 \mathrm{e}-133$ & 83 & 76 & JN651414 & Ethiopia \\
Steinernema sp. & 737 & 486 & $6 \mathrm{e}-133$ & 83 & 76 & JN651413 & Ethiopia \\
Steinernema sp. & 735 & 486 & $6 \mathrm{e}-133$ & 83 & 76 & JN651412 & Ethiopia \\
S. pwaniensis & 939 & 483 & $7 \mathrm{e}-132$ & 85 & 58 & KT358811 & Ethiopia \\
Steinernema sp. & 1060 & 483 & $7 \mathrm{e}-132$ & 85 & 55 & KC252604 & India \\
Steinernema sp. & 911 & 483 & $7 \mathrm{e}-132$ & 85 & 55 & JF834533 & Thailand \\
S. hermaphroditum & 935 & 477 & $3 \mathrm{e}-130$ & 85 & 55 & MF663703 & India \\
S. lamjungense & 815 & 462 & $1 \mathrm{e}-126$ & 87 & 48 & HM000101 & India \\
S. guangdongense & 986 & 459 & $1 \mathrm{e}-124$ & 86 & 49 & AY170341 & China \\
S. longicaudum & 955 & 353 & $6 \mathrm{e}-93$ & 90 & 32 & AY170337 & China \\
S. jeffreyense & 1050 & 379 & $1 \mathrm{e}-108$ & 77 & 55 & KC897093 & S. Africa \\
S. glaseri & 988 & 368 & $2 \mathrm{e}-105$ & 80 & 48 & AF122015 & Belgium \\
Heterorhabditis safricana & 1037 & 41 & $4 \mathrm{e}-07$ & 72 & 7 & EF488006 & S. Africa \\
& & & & & & (Out-group) &
\end{tabular}

The phylogenetic tree showed trichotomy placing the nematode isolate together with selected known Eastern Africa Steinernema spp. (S. pwaniesis, S. ethiopiense, S. karii). The isolate clustered in a clade sub-branch with Steinernema spp. from Kenya (AY230186.1) and Sri Lanka (AY230184.1) with a bootstrap value of 100\% hence least divergent species from the nematode isolate. The other close relative from Kenyan $S$. karii was in a different sub-branch, clustering with Ethiopian species (JN651414.1) S. ethiopense, JN651413.1, and JN651412.1). The rest of the comparative Steinernema species formed a distinct clade with sub-branches. The Heterorhabditis safricana (EF88006) was the most divergent species from the isolate nematode hence more of an out-group among the comparator species (Figure 1). Pairwise sequence alignment between nematode isolate and Steinernema sp. (AY230186.1) revealed 27gaps, and 92\% similarity (Figure 2).

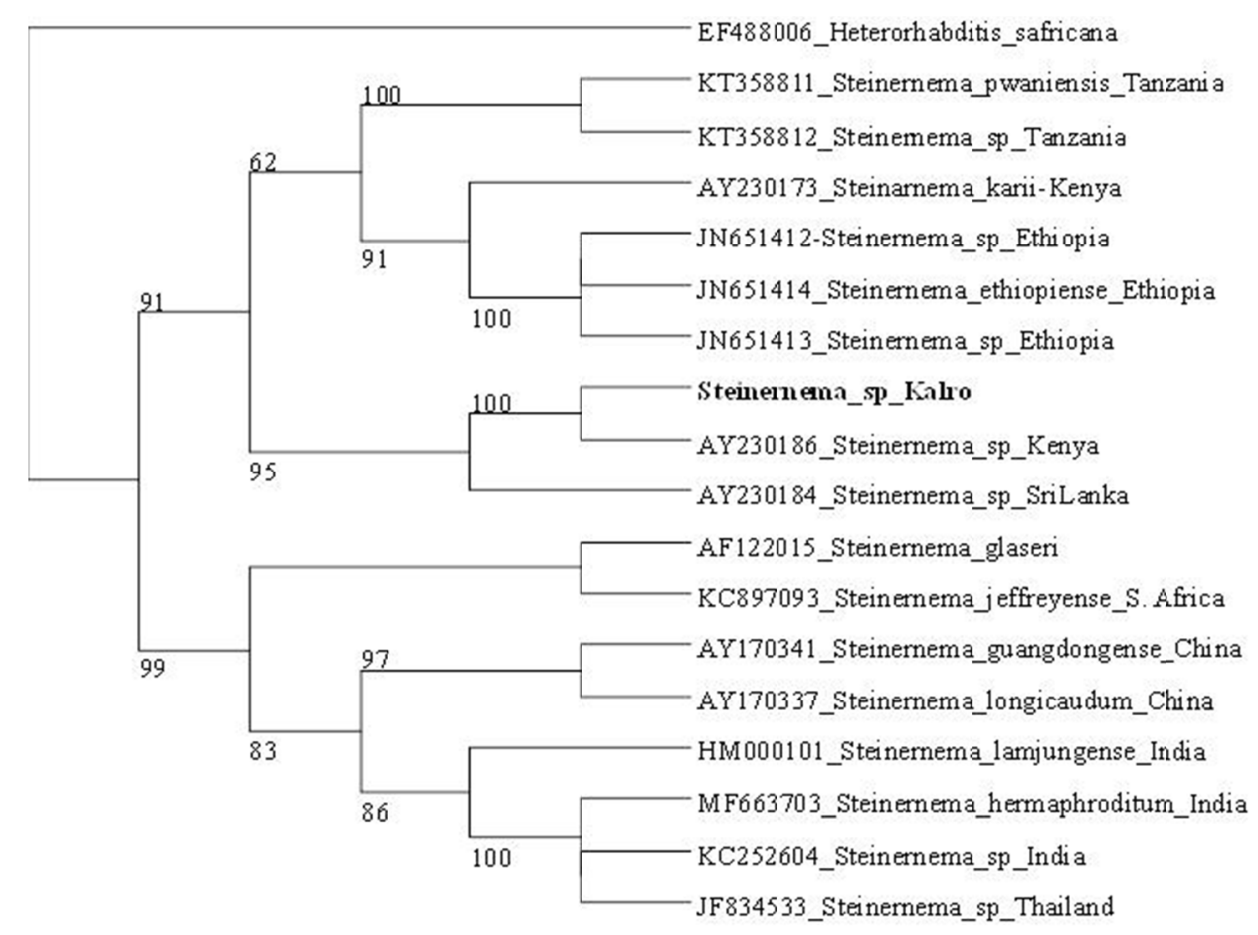

Figure 1. Phylogenetic relationship of entomopathogenic nematode isolate based on analysis of the ITS rDNA through Distance Neighbor-Joining Method 


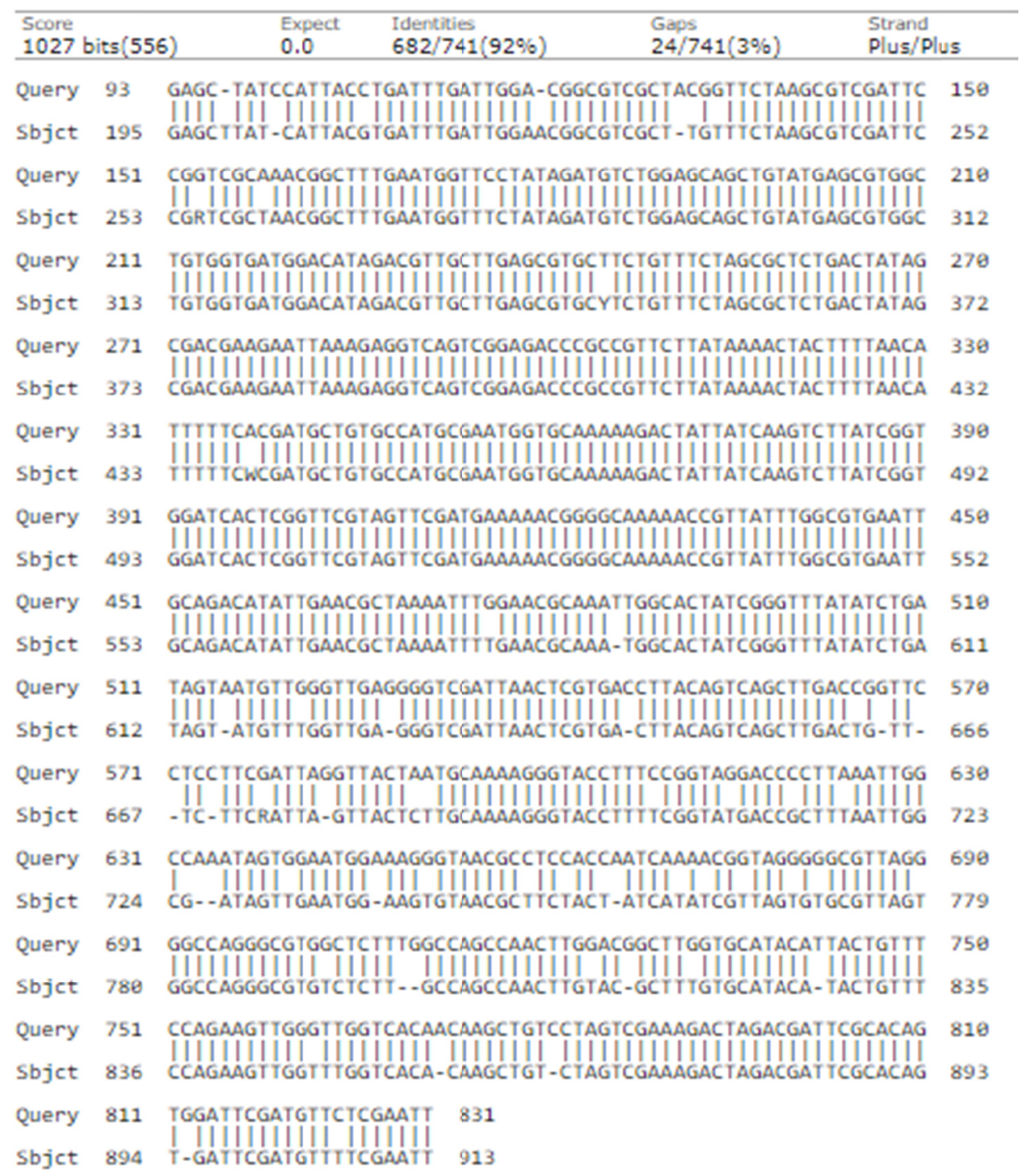

Figure 2. Pairwise alignment of nematode isolate with closest relative Steinernema sp. (AY230186.1)

Note. Query = nematode isolate; Sbjct $=$ Steinernema sp. $($ AY230186.1) .

\subsection{Pathogenicity of the Nematode Isolate against Tuta absoluta}

There was no larval mortality observed in the control treatment ( 0 concentration). The larval stage of Tuta absoluta was susceptible to all the tested doses of entomopathogenic nematode isolate. Maximum mean larval mortality $(80 \% ; 96 \%)$ was achieved 24 and $48 \mathrm{~h}$ post-treatment at IJs concentration 150 . There was a decrease in larval mortality beyond IJs concentration 150 . All nematode concentrations achieved over $50 \%$ mean mortality at $24 \mathrm{~h}$ period. There was a significant difference in larval mortality $(\mathrm{P}<0.001)$ between the control and all the other nematode concentrations. 


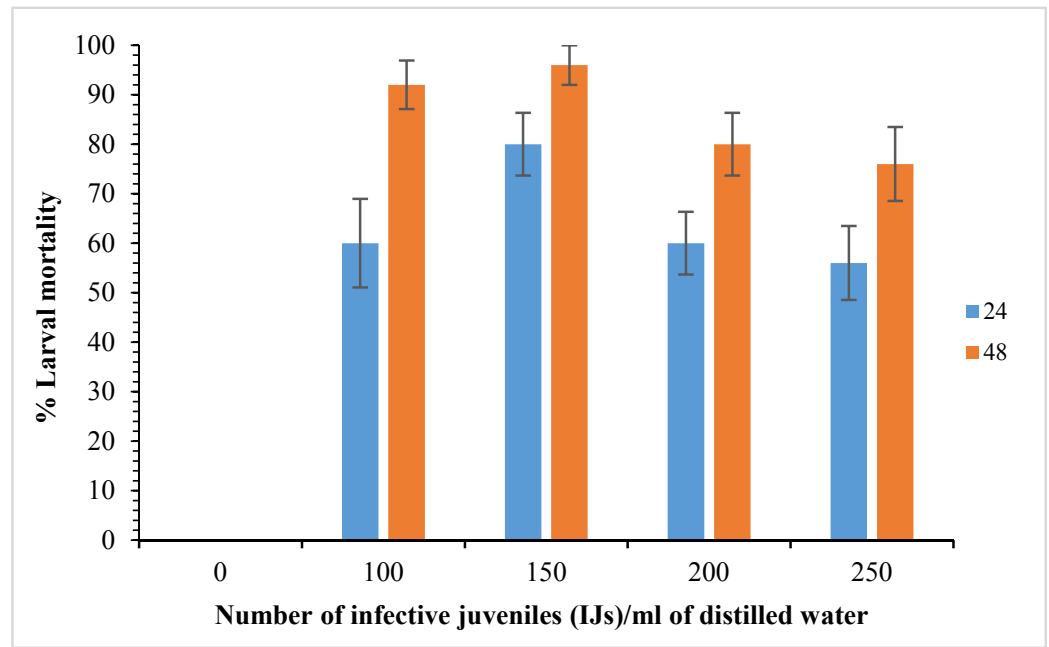

Figure 3. Pathogenicity of entomopathogenic nematode isolate against Tuta absoluta larvae

\section{Discussion}

Morphologically, the isolate lacked a mucron as in S. ethiopense, S. jeffrense, S. pwaniensis, Steinernema karii, and $S$. hermophroditum in their first-generation males. The infective juveniles (IJs), had a tail ( $53 \mu \mathrm{m})$, pharynx $(106 \mu \mathrm{m})$, and hyaline $(20 \mu \mathrm{m})$ length, shorter than the selected close relatives (Waturu et al., 1998; Puza et al., 2015; Malan et al., 2016). Molecular analysis placed EPN isolate together with other Steinernema sp. accessions from gene bank but none gave $100 \%$ match, thus the isolate is suspected to be a new spp. According to Nguyen (2017), the EPNs Steinernema spp. are in five groups namely; feltiae, glaseri, intermedium, carpocapsae, and bicornutum. Based on molecular analysis, most of the "feltiae" group members are found in the "glaseri" group including relatives of nematode isolate; the Steinernema karii (Kenya), S. pwaniensis (Tanzania), S. ethiopense (Ethiopia), and S. jeffreynse (South Africa) all from Africa (Waturu et al., 1998; Malan et al., 2016; Puza et al., 2015). Also, the phylogenic analysis revealed close relatives of EPN isolate outside Africa, S. glaseri (AF122015.1) Belgium, S. guandlongense (AY170341.1) China, S. longicaudum (AY170337.1) China, S. lamjungense (HM000101.1) India, and S. hermaphroditum (MF663703.1) India, are in the "glaseri" group of EPNs (Nguyen, 2017).

The EPN was pathogenic against $T$. absoluta over time and across all the IJs doses. Pathogenicity of EPNs against $T$. absoluta and other economically important agricultural lepidopteran pests has been documented (Salvadori et al., 2012; Kalia et al., 2014; Gozel \& Kasap, 2015; Caoili et al., 2018). There was an increase in mortality rate with an increase in IJs dose of up to 150 . This indicated higher nematode efficiency at a lower concentration. The decrease in mortality at higher IJs concentration could be attributable to competition for entry points, penetration ability, and virulence of nematode in the petri dish bioassay. According to Gulzar et al. (2020), IJs penetration and virulence influence nematode pathogenicity.

\section{Conclusions}

The local nematode isolate was a Steinernema sp. EPNs, based on morphological and molecular analysis. The sequence was deposited to Gene-bank as Steinernema sp. Kalro (Accession MW151701). The EPN has significant potential as a biological control agent against $T$. absoluta. Further taxonomic evaluation of Steinernema sp. Kalro to species level and field trials on efficacy is recommended.

\section{References}

Altschul, S. F., Gish, W., Miller, W., Myers, E. W., \& Lipman, D. J. (1990). Basic Local Alignment search tool. Journal of Molecular Biology, 215, 403-410. https://doi.org/10.1016/S0022-2836(05)80360-2

Altschul, S. F., Madden, T. L., Schaffer, A. A., Zhang, J., Zhang, Z., Miller, W., \& Lipman, D. J. (1997). Gapped BLAST and PSI-BALST: A new generation of protein database search programs. Nucleic Acids Research, 25(17), 3389-3402. https://doi.org/10.1093/nar/25.17.3389

Bedding, R. A., \& Akhurst, R. (1975). A simple technique for the detection of insect parasitic nematodes in the soil. Nematologica, 21, 109-116. https://doi.org/10.1163/187529275X00419

Caoili, B. L., Latina, R. A., Sadoval, R. F., \& Orajay, J. I. (2018). Molecular identification of entomopathogenic 
nematode isolates from the Philippines and their biological control potential against Lepidopteran pests of corn. Journal of Nematology, 50(2), 99-110. https://doi.org/10.21307/jofnem-2018-024

de Brida, A. L., Rosa, J. M., de Oliveira, C. M., de Castro e Castro, B. M., Serrao, J. E., Zanuncio, J. C., ... Wilcken, S. R. (2017). Entomopathogenic nematode in agricultural areas in Brazil. Scientific Report, 7, 45254. https://doi.org/10.1038/srep45254

Edgar, R. C. (2004). MUSCLE: Multiple sequence alignment with high accuracy and throughput. Nucleic Acids Research, 32(5), 1792-1797. https://doi.org/10.1093/nar/gkh340

Gozel, C., \& Kasap, I. (2015). Efficacy of entomopathogenic nematodes against the Tomato Leafminer Tuta absoluta (Meyrick) (Lepidoptera: Gelechiidae) in the tomato field. Turke. Entomolo. Derge., 39(3), 229-237. https://doi.org/10.16970/ted.84972

Gulzar, A., Mukhtar, T., \& Wright, D. J. (2020). Effects of entomopathogenic nematodes Steinernema carpocapsae and Heterorhabditis bacteriophora on the fitness of Vip3A resistant subpopulation of Heliothis virescens (Noctuidae: Lepidoptera). Brigantia, 79(2), 281-292. https://doi.org/10.1590/1678-4499. 20190501

Guoy, M., Guindon, S., \& Gascuel, O. (2010). SeaView version 4: A multiplatform graphical user interface for sequence alignment and phylogenetic tree building. Molecular Biology and Evolution, 27(2), 221-224. https://doi.org/10.1093/molbev/msp259

Hall, T. A. (1999). BioEdit. A user-friendly biological sequence alignment editor and analysis program for Windows 95/98/NT. Nucleic Acids Symposium Series, 41, 95-98.

Kalia, V., Sharma, G., Shapiro-IIan, D. I., \& Ganguly, S. (2014). Biocontrol potential of Steinernema thermophilum and its symbiont Xenorhabdus indica against Lepidopteran pests: virulence to eggs and larval stages. Journal of Nematology, 46(1), 18-26.

Kaushik, C., \& Chaubey, A. K. (2016). Molecular characterization of Steinernema pakistanense (Nematoda Steinernematidae) strain isolated from India. Journal of Zoology Studies, 3(3), 22-26. Retrieved from https://www.journalofzoology.com/archives/article/86/3/3/2016

Liu, J., \& Berry, R. E. (1995). Natural distribution of entomopathogenic nematodes (Rhabditida: Heterorhabditidae and Steinernematidae) in Oregon soils. Environmental Entomology, 24(1), 159-163. https://doi.org/10.1093/ee/24.1.159

Malan, A. P., Knoetze, R., \& Tiedt, L. R. (2016). Steinernema jeffreyense n. sp. (Rhabditida: Steinernematidae), a new entomopathogenic nematode from South Africa-ERRATUM. Journal of Helminthology, 90(3), 262-278. https://doi.org/10.1017/S0022149X15000322

Nguyen, K. B. (2017). Species of Steinernema and species of Heterorhabditis (p. 84). Retrieved from $\mathrm{http}: / /$ entem.ifas.ufi.educ/nguyen/morpho/d2d3-33sp.pdf

Nicolopoulou-Stamati, P., Maipas, S., Kotampasi, C., Stamatis, P., \& Hens, L. (2016). Chemical pesticides and human health: The urgent need for a new concept in agriculture. Frontiers in Public Health, 4, 148. https://doi.org/10.3389/fpubh.2016.00148

PCPB. (2018). Pest control products registered for use in Kenya (6th ed., pp. 1-536). PCPB, Nairobi.

Puza, V., Nermut, Z., Gengler, S., \& Haukeland, S. (2017). Steinernema pwaniensis n. sp., a new entomopathogenic nematode (Nematoda: Steinernematidae) from Tanzania. Journal of Helminthology, 91(1), 20-34. https://doi.org/10.1017/S0022149X15001157

Razia, M., Padmanaban, K., Karthik, R. R., Chellapandi, P., \& Sivaramakrishnan, S. (2011). PCR RFLP pattern analysis of entomopathogenic nematodes isolated from agroecosystem for implicating their genetic diversity. Munis Entomology and Zoology, 6(1), 404-411.

Salvadori, J., Defferiari, M., Ligabue-Braun, R., Lau, E., Salvadori, J., \& Carlini, C. (2012). Characterization of entomopathogenic nematodes and symbiotic bacteria active against Spodoptera frugiperda (Lepidoptera; Noctuidae) and contribution of bacteria urease to insecticidal effect. Biological Control, 63, 253-263. https://doi.org/10.1016/j.biocontrol.2012.08.002

Shapiro-Ilan, D. I., Han, R., \& Dolinksi, D. (2012). Entomopathogenic Nematode Production and Application Technology. Journal of Nematology, 44(2), 206-217. 
Sternberg, P. W., \& Dillman, A. R. (2012). Entomopathogenic Nematodes. Current Biology, 22(11), $430-431$. https://doi.org/10.1016/j.cub.2012.03.047

Waturu, C. N. (1998). Entomopathogenic nematodes (Steinernematidae and Heterorhabdtidae) from Kenya (p. 191, Ph.D. Thesis, University of Reading, UK).

White, G. F. (1927). A method for obtaining infective nematode larvae from cultures. Science, 66(1709), $302-303$. https://doi.org/10.1126/science.66.1709.302-a

Yooyangket, T., Muangpat, P., Polseela, R., Tandhavanat, S., Thanwisai, A., \& Vitta, A. (2018). Identification of entomopathogenic nematodes and symbiotic bacteria from Nam Nao National park in Thailand and larvicidal activity of symbiotic bacteria against Aedes aegypi and Aedes albopictus. PLoS One, 13(4), e019568. https://doi.org/10.1371/journal.pone.0195681

\section{Copyrights}

Copyright for this article is retained by the author(s), with first publication rights granted to the journal.

This is an open-access article distributed under the terms and conditions of the Creative Commons Attribution license (http://creativecommons.org/licenses/by/4.0/). 